\title{
IL-21 in Homeostasis of Resident Memory and Exhausted CD8 T cells during Persistent Infection
}

\author{
Heather M. Ren and Aron E. Lukacher *(D) \\ Department of Microbiology and Immunology, The Pennsylvania State University College of Medicine, \\ Hershey, PA 17033, USA; hschmitz@pennstatehealth.psu.edu \\ * Correspondence: alukacher@pennstatehealth.psu.edu
}

Received: 31 August 2020; Accepted: 20 September 2020; Published: 22 September 2020

\begin{abstract}
CD4 T cells guide the development of CD8 T cells into memory by elaborating mitogenic and differentiation factors and by licensing professional antigen-presenting cells. CD4 T cells also act to stave off $\mathrm{CD} 8 \mathrm{~T}$ cell dysfunction during repetitive antigen stimulation in persistent infection and cancer by mitigating generation of exhausted $\mathrm{T}$ cells $\left(\mathrm{T}_{\mathrm{EX}}\right)$. CD4 $\mathrm{T}$ cell help is also required for establishing and maintaining tissue-resident memory $\mathrm{T}$ cells $\left(\mathrm{T}_{\mathrm{RM}}\right)$, the nonrecirculating memory $T$ cell subset parked in nonlymphoid tissues to provide frontline defense against reinvading pathogens. Interleukin (IL)-21 is the signature cytokine secreted by follicular helper CD4 T cells $\left(\mathrm{T}_{\mathrm{FH}}\right.$ ) to drive $\mathrm{B}$ cell expansion and differentiation in germinal centers to mount high-affinity, isotype class-switched antibodies. In several infection models, IL-21 has been identified as the CD4 T help needed for formation and survival of $\mathrm{T}_{\mathrm{RM}}$ and $\mathrm{T}_{\mathrm{EX}}$. In this review, we will explore the different memory subsets of CD8 T cells in persistent infections, the metabolic profiles associated with each, and evidence documenting the importance of CD4 T cell-derived IL-21 in regulating CD8 $\mathrm{T}_{\mathrm{RM}}$ and $\mathrm{T}_{\mathrm{EX}}$ development, homeostasis, and function.
\end{abstract}

Keywords: interleukin (IL)-21; CD8 T cells; CD4 T cells; resident memory; exhaustion; persistent infection

\section{Introduction}

CD8 $T$ cells are broadly demarcated into naïve, effector $\left(\mathrm{T}_{\mathrm{EFF}}\right)$, central memory $\left(\mathrm{T}_{\mathrm{CM}}\right)$, effector memory $\left(\mathrm{T}_{\mathrm{EM}}\right)$, resident memory $\left(\mathrm{T}_{\mathrm{RM}}\right)$, and exhausted $\left(\mathrm{T}_{\mathrm{EX}}\right)$ subsets $[1,2]$. These classifications are based on expression of specific surface molecules, transcription factors, enzymes, and their anatomic location (Figure 1). These distinctions may be blurred by systemic and local inflammatory conditions that allow $\mathrm{T}$ cells to acquire features of other subsets [3]. For example, CD8 T cells responding to persistent infections in nonlymphoid tissues often share features of both $\mathrm{T}_{\mathrm{RM}}$ and $\mathrm{T}_{\mathrm{EX}}$. Despite these caveats, $\mathrm{T}$ cell subsetting provides a useful framework to interpret $\mathrm{T}$ cell responses to cancer, infections, vaccines, and immunomodulatory therapies [4].

Recent literature indicates an essential role for CD4 T cells to help CD8 T cells differentiate into $\mathrm{T}_{\mathrm{EX}}$ and $\mathrm{T}_{\mathrm{RM}}$ during chronic systemic and CNS-localized lymphocytic choriomeningitis virus (LCMV) infections, respectively $[5,6]$, and into a mixed $\mathrm{T}_{\mathrm{EX}}-\mathrm{T}_{\mathrm{RM}}$ state in persistent brain infections by Toxoplasma gondii and mouse polyomavirus (MuPyV) [7-9]. Recent studies from several groups have implicated interleukin (IL)-21 as the central cytokine produced by CD4 $\mathrm{T}$ cells that preserves the function in $\mathrm{T}_{\mathrm{EX}}$ and promotes $\mathrm{T}_{\mathrm{RM}}$ differentiation [10-16]. In light of the overlapping characteristics between $\mathrm{T}_{\mathrm{EX}}$ and $\mathrm{T}_{\mathrm{RM}}$ by CD8 $\mathrm{T}$ cells in the setting of persistent viral infections in nonlymphoid tissues, this review will focus on $\mathrm{T}_{\mathrm{RM}}$ and $\mathrm{T}_{\mathrm{EX}}$ during persistent infections and discuss how CD4 T cell-derived IL-21 helps CD8 $\mathrm{T}$ cells belonging to these subsets maximize functionality and minimize collateral tissue damage. 


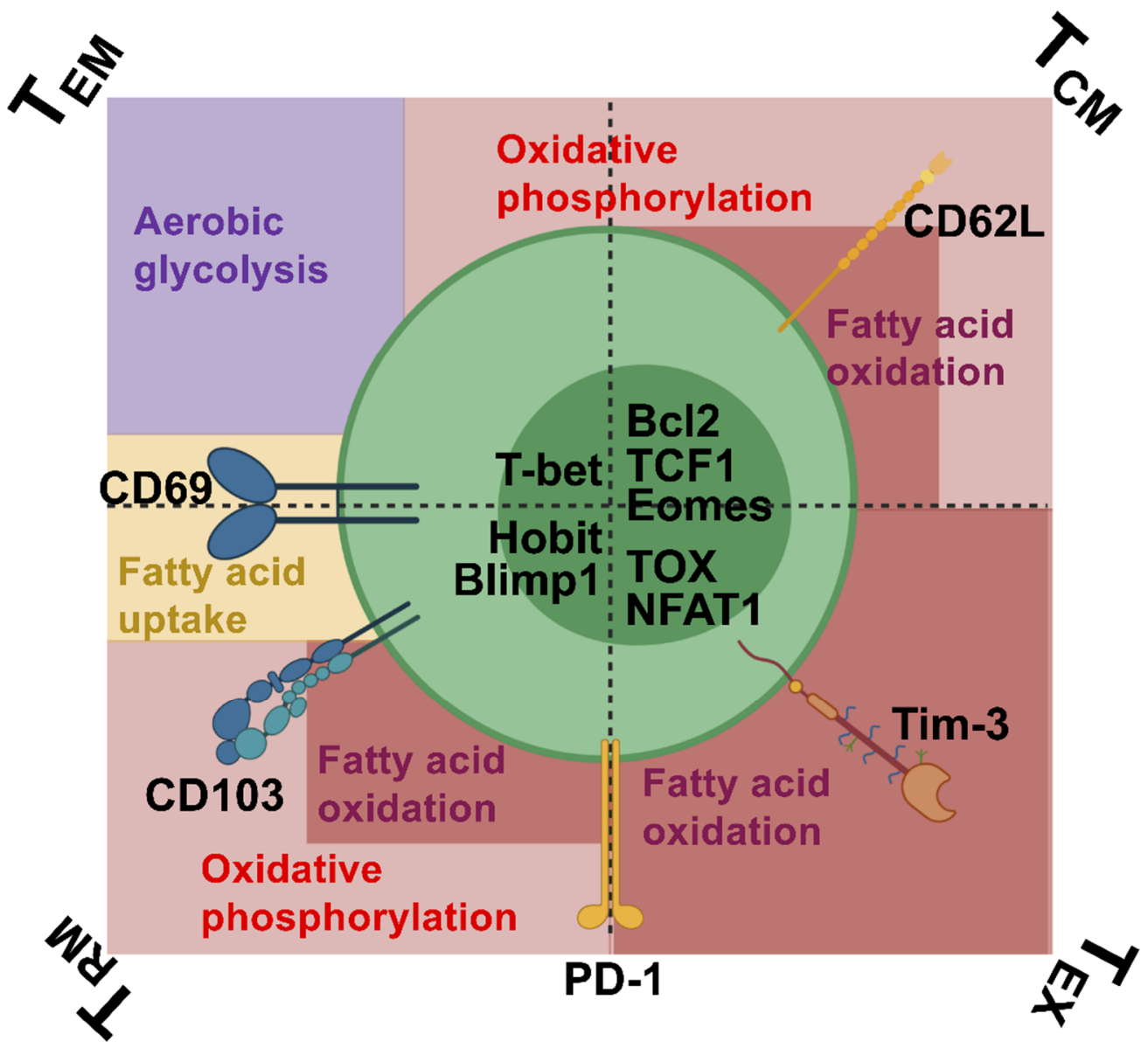

Figure 1. CD8 T cell memory subsets. CD8 T cells are classified as various memory subsets based on their expression of certain transcription factors, surface molecules, and metabolic profiles. As depicted here, there is fluidity and overlap in these memory profiles. Figure image created with BioRender.com.

\section{CD8 T cell Memory Subsets}

Memory subsets differ in migratory behavior: $\mathrm{T}_{\mathrm{EM}}$ circulate through the lymphatic and blood vasculature, as well as nonlymphoid tissues, with the ability to rapidly infiltrate sites of active infection/inflammation; $\mathrm{T}_{\mathrm{CM}}$ circulate through the lymph and blood; $\mathrm{T}_{\mathrm{RM}}$ are permanently settled in nonlymphoid tissues; and $\mathrm{T}_{\mathrm{EX}}$ can persist long-term in nonlymphoid tissues and/or lymph nodes draining tissues "contaminated" with chronic antigen (e.g., neoplasia and persistent infection) $[17,18]$. $\mathrm{T}_{\mathrm{EX}}$ are not conventional memory $\mathrm{T}$ cells, but rather are comprised of transcriptionally and phenotypically distinct subsets organized in an intricate precursor-progeny relationship [19,20]. Note that there are exceptions to these working memory subset designations, such as recent evidence that $\mathrm{T}_{\mathrm{RM}}$ can leave tissues and migrate to draining lymph nodes where they can transmogrify into $\mathrm{T}_{\mathrm{CM}}$ and reenter the circulation [21-23].

As shown in Figure 1, $\mathrm{T}_{\mathrm{EM}}$ express the T-box transcription factor T-bet (Tbx21), which has been found to regulate expression of the lymphocyte trafficking chemokine CXCR3 and the production of the lymphocyte effector cytokine IFN $\gamma$ [24]. $\mathrm{T}_{\mathrm{CM}}$ express $\mathrm{Bcl} 2$, as well as the transcription factors $\mathrm{T}$ cell factor 1 (TCF-1) and Eomesodermin (Eomes). Bcl2 localizes to the outer membrane of mitochondria to promote cellular survival and inhibit proapoptotic proteins such as Bax and Bak which are known to promote release of cytochrome $C$ and reactive oxygen species. TCF-1, downstream of the canonical Wnt signaling pathway, binds Eomes in CD8 T cells and induces memory formation. Blimp1 (B lymphocyte-induced maturation protein 1) and its homolog Hobit (homologue of Blimp1 in T cells) are expressed by $\mathrm{T}_{\mathrm{RM}}$ [25]. Blimp1, the protein encoded by Prdm1, and Hobit bind target 
sequences within the S1pr1, Ccr7, and Tcf7 loci, which likely directly represses these genes and, in turn, prevents cell egress from the tissues [25]. In addition to TCF-1 and Eomes, $\mathrm{T}_{\mathrm{EX}}$ express TCR-responsive transcription factors such as NFAT1, IRF4, BATF, and TOX that are involved in driving their dysfunctional state [26-33].

As $\mathrm{T}_{\mathrm{EM}}$ migrate into tissues, lymph, and blood, they may transiently alter expression of surface receptors to allow retention in tissues. One such molecule that $\mathrm{T}_{\mathrm{EM}}$ can transiently upregulate is the C-type lectin CD69. CD69 forms a complex with sphingosine phosphate-1 (S1P1), causing its internalization and destruction such that the cell no longer responds to S1P gradients (high in vasculature, low in tissues) [34]. Conversely, transcriptional downregulation of the S1P1 receptor (S1PR1) is associated with increased CD69 expression, but this may not be causally related [35]. $\mathrm{T}_{\mathrm{CM}}$ notably do not express CD69 and are CD62L(L-selectin) ${ }^{\text {hi }}$. Like CD69 expression in certain lymphocyte subsets, expression of the CD62L lymph node homing receptor dictates migration patterns. CD62L can bind GlyCAM-1 on high endothelial venules of lymph nodes to facilitate entry into secondary lymph organs where $\mathrm{T}_{\mathrm{CM}}$ are commonly found as they migrate through the lymph and blood. Like $\mathrm{T}_{\mathrm{EM}}, \mathrm{T}_{\mathrm{RM}}$ are $\mathrm{CD} 62 \mathrm{~L}^{\text {lo }}$ and express surface $\mathrm{CD} 69$ to promote tissue retention [36,37]. $\mathrm{T}_{\mathrm{RM}}$ may also be $\mathrm{CD} 103^{\mathrm{hi}}$ and/or PD-1 ${ }^{\mathrm{hi}}$ [35-38]. The $\mathrm{CD} 103(\alpha \mathrm{E})$ subunit pairs with $\beta 7$ to form an integrin heterodimer, whose ligand is E-cadherin. E-cadherin $-\alpha E \beta 7$ binding is thought to tether $T_{R M}$ to epithelial cells. CD103 as it relates to $\mathrm{bT}_{\mathrm{RM}}$ is discussed more thoroughly below. Like CD103, PD-1 expression by $T_{R M}$ is tissue- and pathogen-dependent [39]. CD103 is expressed by most $T_{R M}$ in the skin, but by fewer CD8 $\mathrm{T}_{\mathrm{RM}}$ in the brain [7,36,40-42]; PD-1 (also discussed below) is expressed by most $\mathrm{T}_{\mathrm{RM}}$ in the brain but is less commonly seen on skin $\mathrm{T}_{\mathrm{RM}}[38,39,43,44]$. $\mathrm{T}_{\mathrm{EX}}$ also express PD-1 as well as multiple inhibitory receptors (e.g., Lag-3, 2B4, TIM-3, and CD160) depending on the severity and duration of persistent infection [26]. The constellation of inhibitory receptors expressed by a $\mathrm{T}$ cell indicates the level of dysfunction, with recent work ascribing expression of inhibitory receptors to different $\mathrm{T}_{\mathrm{EX}}$ stages $[19,45]$.

The metabolic profile of each of the memory subsets differs and influences both longevity and function. $\mathrm{T}_{\mathrm{EM}}$ primarily utilize aerobic glycolysis, with some reliance on oxidative phosphorylation and fatty acid uptake [34,46]. $\mathrm{T}_{\mathrm{CM}}$ are biased toward oxidative phosphorylation and support fatty acid oxidation (FAO) in a tissue-dependent manner [46]. $\mathrm{T}_{\mathrm{RM}}$ share a metabolic profile with $\mathrm{T}_{\mathrm{CM}}$, but may uptake exogenous fatty acids from their tissue microenvironment to support FAO in a be tissue-dependent fashion [47,48]. $\mathrm{T}_{\mathrm{EX}}$ have altered metabolism (i.e., dysregulated glycolysis and mitochondrial metabolism) and rely on lipolysis to fuel FAO [49]. Understanding how metabolism shapes memory $\mathrm{T}$ cell differentiation is an active area of investigation.

\section{3. $T_{R M}$ : Regional Immunosurveillance}

$\mathrm{T}_{\mathrm{RM}}$ are defined by their ability to sojourn long-term in nonlymphoid tissue (e.g., skin, lung, and brain) without needing to be resupplied by circulating $\mathrm{T}_{\mathrm{EFF}}$ [50]. In the antiviral response, when $T_{R M}$ re-encounter cells expressing their cognate viral antigen, they proliferate, differentiate into effector cells with the capacity to directly kill infected cells, release antiviral molecules such as IFN $\gamma$ and TNF $\alpha$, and secrete chemokines to recruit other immune cells to the site of infection [51,52]. These immediate effector and sentinel alarm activities quickly act to control infections in nonlymphoid tissues [51,52], and are considered to be more effective than the memory response mounted by their circulating counterparts. There are several methods of experimentally defining a cell as $\mathrm{T}_{\mathrm{RM}}$ (Table 1, [18]). Each method has its advantages, although the appropriateness of each approach may depend on the nonlymphoid tissue being studied. 
Table 1. Methods to define $\mathrm{T}_{\mathrm{RM}}$.

\begin{tabular}{|c|c|c|c|}
\hline Method & Description & Advantage(s) & Limitation(s) \\
\hline Parabiosis [53] & $\begin{array}{l}\text { Congenically distinct mice } \\
\text { are joined via skin flaps that } \\
\text { allows their vasculature to } \\
\text { anastomose so that in } \sim 2 \\
\text { weeks, blood contains equal } \\
\text { cells of each partner }\end{array}$ & $\begin{array}{l}\text { - shows whether the cells are } \\
\text { maintained independent of } \\
\text { vascular input } \\
\text { can be tested over } \\
\text { many weeks } \\
\text { - can assess all organs/tissues } \\
\text { at once }\end{array}$ & $\begin{array}{l}\text { - } \quad \text { intensive procedure } \\
\text { - } \text { not appropriate for } \\
\text { chronic infection } \\
\text { - } \quad \text { can be difficult to interpret if } \\
\text { the T cell population is } \\
\text { mixed in the tissue(s) } \\
\text { cannot assess cell egress from } \\
\text { tissue of interest }\end{array}$ \\
\hline Tissue transplant & $\begin{array}{l}\text { Tissue from a congenically } \\
\text { distinct subject is } \\
\text { transplanted onto another }\end{array}$ & $\begin{array}{l}\text { can answer whether } \\
\text { hosT cells enter the } \\
\text { transplant tissue and } \\
\text { whether transplanT cells exit }\end{array}$ & $\begin{array}{l}\text { - } \\
\text { not appropriate for } \\
\text { chronic infection } \\
\text { inflammation induced by } \\
\text { graft surgery could } \\
\text { influence results } \\
\text { - } \quad \text { only appropriate for organs } \\
\text { that are easily transplanted } \\
\text { (e.g., skin) }\end{array}$ \\
\hline Photo-conversion [54] & $\begin{array}{l}\text { Photo-convert transgenic } \\
\text { cells (e.g., Kaede-expressing } \\
\text { cells irreversibly change } \\
\text { from green to red when } \\
\text { exposed to violet light) }\end{array}$ & $\begin{array}{l}\text { - can assess infiltration and } \\
\text { egress of cells from a tissue } \\
\text { can work for } \\
\text { chronic infection }\end{array}$ & $\begin{array}{l}\text { - limited by access of tissue to } \\
\text { the violet light source } \\
\text { protein turnover means } \\
\text { converted fluorescent signal } \\
\text { is lost in } \sim 1 \text { week }\end{array}$ \\
\hline Dye-label & $\begin{array}{c}\text { Inject a fluorescent dye into } \\
\text { the tissues (e.g., CSFE) to } \\
\text { label local cells }\end{array}$ & $\begin{array}{l}\text { - } \quad \text { assesses infiltration and } \\
\text { egress of cells from a tissue } \\
\text { can work for } \\
\text { chronic infection }\end{array}$ & $\begin{array}{l}\text { - dye diffusion away from } \\
\text { local site can result in } \\
\text { unintended cells } \\
\text { getting labeled } \\
\text { can have incomplete labeling } \\
\text { of target cells } \\
\text { - loss of dye-labeling if cells } \\
\text { proliferate may result in the } \\
\text { cells of interest no longer } \\
\text { being labelled }\end{array}$ \\
\hline $\begin{array}{c}\text { Intravascular antibody } \\
\text { labeling [55] }\end{array}$ & $\begin{array}{l}\text { Inject anti-CD45 (or } \\
\text { anti-CD8, etc) i.v. } 3 \text { min } \\
\text { prior to euthanization }\end{array}$ & $\begin{array}{ll}\text { - } & \text { reveals location of cells } \\
\text { (vasculature vs. parenchyma) } \\
\text { - } \quad \text { can work for } \\
\text { chronic infection } \\
\text { - } \quad \text { works well for highly } \\
\text { vascularized tissue } \\
\text { (e.g., lung) }\end{array}$ & $\begin{array}{l}\text { - does not reveal } \\
\text { migration history } \\
\text { can only determine cell } \\
\text { location at time } \\
\text { of euthanization }\end{array}$ \\
\hline $\begin{array}{c}\text { Peripheral } \\
\text { antibody-mediated T cell } \\
\text { depletion [44] }\end{array}$ & $\begin{array}{c}\text { Inject anti-CD8 (or } \\
\text { anti-Thy1.1, etc.) i.p. starting } \\
\text { 8-10 dpi }\end{array}$ & $\begin{array}{l}\text { can show cells are } \\
\text { maintained independent } \\
\text { of vasculature } \\
\text { works well for solid organs } \\
\text { with minimal antibody } \\
\text { infiltration (e.g., brain, skin) } \\
\text { can work for } \\
\text { chronic infection } \\
\text { can assess multiple } \\
\text { organs/tissues at once }\end{array}$ & $\begin{array}{l}\text { - } \\
\text { tissue(s) of interest } \\
\text { limited use for tissues that } \\
\text { are highly vascularized } \\
\text { and/or mucosal if antibody } \\
\text { can easily penetrate and } \\
\text { deplete these cells }\end{array}$ \\
\hline
\end{tabular}

Although $\mathrm{T}_{\mathrm{RM}}$ have a number of generally accepted defining characteristics (i.e., maintenance in nonlymphoid tissues independent of vasculature input), they are phenotypically flexible. The tissue and pathogen context dictate expression of certain molecules by $\mathrm{T}_{\mathrm{RM}}$ and may be involved in facilitating regional immunosurveillance. Some of the tissue-specific features may be attributed to whether the tissue is a barrier/mucosal site (e.g., skin, respiratory tract, female reproductive tract, or gastrointestinal tract) comprised of rapidly dividing cells to repair tissue damage, or a nonmucosal site (e.g., central nervous system), whose terminally differentiated cells necessitate a finely tuned immune response to limit tissue injury. Brain (b) $\mathrm{T}_{\mathrm{RM}}$, in particular, are charged with balancing pathogen control and immunopathology. For example, LCMV-specific CD8 bT $\mathrm{RM}_{\text {M }}$ can control LCMV intracranial (i.c.) re-infection in the absence of CD8 $\mathrm{T}_{\mathrm{CM}}$ and $\mathrm{T}_{\mathrm{EM}}$ [41]; in contrast, LCMV i.c. infection in naïve immunocompetent mice is lethal as a result of antiviral CD8 T cell-mediated immunopathology in the brain [56]. 


\section{4. $T_{E X}$ : Pathogen-Specific Control}

Our understanding of $\mathrm{T}_{\mathrm{EX}}$ biology comes largely from studies involving experimental chronic LCMV (clone 13 and DOCILE strain) infection and mouse cancer models. An expanding body of data support the concept that $\mathrm{T}_{\mathrm{EX}}$ are a distinct $\mathrm{T}$ cell differentiation state epigenetically programmed by repetitive TCR stimulation $[57,58]$. Recent work shows that $\mathrm{T}_{\mathrm{EX}}$ consist of self-renewing progenitors that progress to a terminal, nonproliferative, nonfunctional state [19], with a concomitant increase in PD-1 and other inhibitory receptors [2,59-61]. With regard to cancer studies, CD8 T cell exhaustion is considered pathological because the tumor survives and expands in part due to the reduced effector function of exhausted CD8 T cells, as underscored by the success of checkpoint inhibitor blockade (CIB) cancer immunotherapy. Yet, the effectiveness of CIB therapy is frustratingly nonuniform among different types of cancer (e.g., melanoma and certain lung carcinomas generally respond well to CIB therapy, whereas solid tumors in the liver and colon are unlikely to respond), as well as the variable success among patients with similar types and stages of cancers. Varying degrees of antitumor $\mathrm{T}$ cell exhaustion at the time of CIB initiation may affect the level of response. One possibility is that $\mathrm{CIB}$ therapy primarily targets the progenitor $\mathrm{T}_{\mathrm{EX}}$, whose frequency may vary among different types of cancer.

Recent studies have stratified the responsiveness of $\mathrm{T}_{\mathrm{EX}}$ based on their expression of various molecules (e.g., PD-1 and other checkpoint inhibitory receptors, Eomes, Blimp1, TOX, and NFAT1) and the chemokine receptor CXCR5. High TCF-1 expression in CD8 T cells during LCMV Clone 13 infection has been linked to a "stem cell-like" phenotype [62]. The more practical and clinically relevant implication of these recent data is that TCF-1 ${ }^{\text {hi }} \mathrm{PD}-1^{+} \mathrm{CXCR} 5^{+} \mathrm{CD} 8 \mathrm{~T}$ cells, which are found primarily in the lymph nodes, respond to PD-1/PD-L1 blockade and are considered the precursors to the terminally differentiated non-PD-1/PD-L1 blockade responders [63]. Against infectious pathogens in the brain, the reduced effector function by CD8 $\mathrm{T}_{\mathrm{EX}}$ may sacrifice efficiency in clearing infection, and tolerate pathogen persistence for the sake of reducing tissue damage [38,43].

\section{CD103 in the CNS}

CD103 is often used as a $T_{R M}$ marker, albeit the fraction of $T_{R M}$ bearing surface CD103 varies depending on the tissue examined and type of microbial pathogen studied [38]. CD103 is induced by transforming growth factor (TGF)- $\beta$ signaling $[36,64,65]$, but whether TGF- $\beta$ is responsible for differences in CD103 expression by $\mathrm{T}_{\mathrm{RM}}$ in different tissues remains to be determined. As stated above, the CD103 integrin is generally thought to tether $T_{R M}$ to epithelial cells, but there is little evidence for E-cadherin expression in the CNS [42]. Furthermore, CD8 T cells isolated from brains of mice infected with $T$. gondii vary in CD103 expression, with no overt difference in their location or function between $\mathrm{CD}_{103}{ }^{+}$and $\mathrm{CD}_{103}{ }^{-}$populations [7,42]. CD103 expression has been linked with T. gondii-specific CD8 $\mathrm{bT}_{\mathrm{RM}}$ that have higher TCR affinities, suggesting that its expression is related to high TCR stimulation during activation [66], but this remains correlative. A recent study of T cells in human brains also found a $40 / 60 \%$ split of $\mathrm{CD} 103^{+} / \mathrm{CD} 103^{-} \mathrm{CD} 8 \mathrm{~T}$ cells; there, CD103 expression correlated with upregulation of homing markers, but without a difference in localization [67]. Interestingly, in both mice and humans, there appears to be an inverse relationship between PD- 1 and CD103 expression by CD8 $T_{R M}[43,68]$. Thus, CD103 expression is an imperfect $\mathrm{T}_{\mathrm{RM}}$ marker and may not be involved in CNS localization; moreover, whether PD-1 regulates CD103 expression or possibly fosters survival of CD103- CD8 T cells remains to be determined.

\section{PD-1 as Neuroprotective}

The signature inhibitory receptor for $\mathrm{T}_{\mathrm{EX}}$ is $\mathrm{PD}-1$. However, $\mathrm{PD}-1$ does not define the cell as $\mathrm{T}_{\mathrm{EX}}$ per se, because recently activated effector CD8 T cells also express PD-1 [69]. Assigning T cells to an exhausted state requires demonstrating loss of effector functionality, such as decreased cytokine production. In the MuPyV CNS infection model, $\mathrm{PD}-1$ is highly expressed on $\mathrm{CD} 8 \mathrm{bT}_{\mathrm{RM}}$, but not splenic 


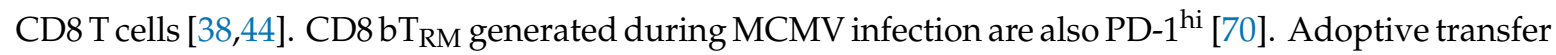
studies of $\mathrm{bT}_{\mathrm{RM}}$ and the finding that the Pdcd1 locus of brain CD8 T cells, but not spleen CD8 T cells, was demethylated supports that PD-1 expression is intrinsic to $\mathrm{bT}_{\mathrm{RM}}$ [38]. Nanostring gene expression analysis of the PD-L1 ${ }^{-/-}$brain microenvironment suggests that the PD-1:PD-L1 pathway decreases neuroinflammation during MuPyV infection [43], further indicating that PD-1 on bT RM $_{\text {protects against }}$ CNS damage. T cells isolated from 26 post-mortem brains from patients who died of non-CNS disease showed that both PD-1 and CTLA-4 are expressed by human brain CD8 T cells, but not CD8 T cells in blood [67]. This analysis lends support to the idea that the brain environment is responsible for upregulating inhibitory receptors on CNS-infiltrating CD8 T cells. PD-1 expression appears to be limited to $\mathrm{CD} 8 \mathrm{~T}$ cells generated against chronic viral infections as few of the CD8 $\mathrm{T}_{\mathrm{RM}}$, including those in the brain, generated during acute infections express PD-1 [38,40,70-72]. Notably, PD-1 blockade therapy has shown benefit in progressive multifocal leukoencephalopathy, a life-threatening demyelinating brain disease caused by the JC polyomavirus [73,74]. Interestingly, PD-1 may have an impact on the metabolic profile of the cell. In gastric adenocarcinoma, for example, PD-L1 blockade resulted in an increase in fatty acid binding protein (FABP) $4 / 5$ expression [75], suggesting that PD-1 signaling has a negative association with free fatty acid uptake and may result in the cell situated along a spectrum of $\mathrm{T}_{\mathrm{RM}} / \mathrm{T}_{\mathrm{EX}}$ rather than $\mathrm{T}_{\mathrm{EM}} / \mathrm{T}_{\mathrm{RM}}$ differentiation. Persistent antigen and/or virus-associated inflammation during chronic infections induce PD-1 on brain-infiltrating T cells. Although TCR stimulation drives PD-1 expression, maintenance of PD-1 may be antigen-independent [38]. An important area of future research will be to define the factors sustaining PD-1 expression by $\mathrm{CD} 8 \mathrm{bT} \mathrm{RM}_{\mathrm{RM}}$.

\section{CD4 T cells: The CD8 $T_{R M}$ and $T_{E X}$ Helpers}

Multiple lines of evidence document the importance of CD4 T cell help in directing the differentiation of naïve CD8 $\mathrm{T}$ cells $[5-7,9,48,76]$. During priming (the accumulation of signals during the initial activation of CD8 T cells when they encounter their cognate peptide), this help is predominantly through CD4 T cell "licensing" of dendritic cells and other antigen presenting cells to express costimulatory molecules required to initiate $\mathrm{T}$ cell differentiation. Recent studies have revealed that CD4 $\mathrm{T}$ cell help also contributes to effector and memory stages of CD8 T cell differentiation $[7,77]$.

In the female reproductive tract (FRT) during HSV-2 infection, CD4 T cells produce IFN $\gamma$ to stimulate the production of the chemokines CXCL9 and CXCL10 prior to CD8 T cell entry of the tissues [78]. These chemokines bind CXCR3, which is expressed by effector CD8 T cells. CXCL9/10 gradients attract CXCR3 ${ }^{\text {hi }}$ CD8 T cells to the FRT; it is this CD4 T cell-directed entry into the tissue that initiates $\mathrm{T}_{\mathrm{RM}}$ differentiation [78]. CD4 T cell-derived IFN $\gamma$ was further found to be required for CD8 $\mathrm{T}$ cell entry into the lung and for CD103 upregulation on the CD8 T cells during influenza infection [76], suggesting that IFN $\gamma$ could both indirectly and directly initiate CD8 $\mathrm{T}_{\mathrm{RM}}$ differentiation.

Coincident with reports implicating IFN $\gamma$ as the CD4 T cell-derived help for CD8 $\mathrm{T}_{\mathrm{RM}}$, IL-21 was described as a potential mechanism of CD4 T cell help. In 2009, a trilogy of articles in Science introduced the idea that IL-21 was essential for rescuing CD8 T cells from exhaustion during systemic chronic LCMV infection [10-12]. CD4 T cells in the brain produce IL-21 during early infection by the gliatropic JHMV coronavirus and CD8 T cells upregulate the IL-21 receptor (IL21R); notably, IL21R ${ }^{-1-}$ CD8 T cells have impaired granzyme B and IFN $\gamma$ production $[79,80]$. IL-21 from CD4 T cells was also found to limit exhaustion and promote effector functionality of CD8 T cells in T. gondii brain infection [15]. Recently, we determined that IL-21 promotes CD8 $\mathrm{bT}_{\mathrm{RM}}$ differentiation during MuPyV infection [81].

\section{IL-21: Production and Signaling}

IL-21 is primarily considered a CD4 T cell-derived cytokine, although other cell types such as NKT cells, B cells, CD8 T cells, macrophages, and dendritic cells have been reported to express low levels of IL21 transcripts [12,82]. IL21 is the hallmark $\mathrm{T}_{\mathrm{FH}}$ cytokine due to its essential role in sustaining the germinal center reaction and providing help to $\mathrm{B}$ cells for T-dependent antibody responses $[83,84]$. Yet, non-follicular $\mathrm{CD} 4 \mathrm{~T}$ cells with $\mathrm{T}_{\mathrm{FH}}$ characteristics have been described and identified as sources 
of IL-21 in nonlymphoid tissues. Increased numbers of circulating PD-1 ${ }^{\text {hi }}$ CXCR5 ${ }^{+}$CD4 T cells are associated with elevated IL-21 in sera of patients with cystic echinococcosis [85]. CXCR5 ${ }^{+}$ICOS $^{+}$ memory CD4 T cells have also been detected in the blood of multiple sclerosis patients, which is positively correlated with higher IL-21 plasma levels and Expanded Disability Status scores [86]. In the brain, $\mathrm{CXCR} 5^{+} \mathrm{PD}-1^{+} \mathrm{CD} 4 \mathrm{~T}$ cells have been found in a murine model of neuropsychiatric lupus, and these cells produce IL-21 and IFN $\gamma$ upon ex vivo stimulation [87]. More recently, we have found that CXCR5 $5^{\text {hi }}$ PD- $1^{\text {hi }}$ CD4 T cells in the brain of MuPyV-infected mice produce IL-21 [81]. These cells have transcriptional, phenotypic, and functional overlap with $\mathrm{T}$ helper type $1\left(\mathrm{~T}_{\mathrm{H}} 1\right) \mathrm{CD} 4 \mathrm{~T}$ cells lending greater appreciation to the idea for the existence of a distinct helper CD4 T cell subset with properties shared by $\mathrm{T}_{\mathrm{H}} 1$ and $\mathrm{T}_{\mathrm{FH}}$ cells [81]; however, lineage tracing studies are needed to determine whether these nonlymphoid CD4 $\mathrm{T}$ cells constitute a distinct helper subset.

TCR stimulation influences IL-21 production by CD4 T cells [82] as do particular cytokines (e.g., IFN $\alpha / \beta$ ) [88]. IL-21 itself is one of the cytokines used to polarize naïve CD4 $\mathrm{T}$ cells into $\mathrm{T}_{\mathrm{FH}}$, suggesting that IL-21 provides autocrine signaling to influence its own production [89]. IL-21 may also be produced by CD4 T cells in concert with high TCR stimulation [81,90]. Recent work by Ditoro et al. showed that IL-2 production by naïve CD4 T cells is associated with high TCR affinity and their formation into IL-21-producing $\mathrm{T}_{\mathrm{FH}}$ during protein immunization and/or Listeria monocytogenes infection [90]. We showed that during MuPyV brain infection, IL-21-producing CD4 T cells in the CNS expressed higher affinity TCRs than the IL-21-non-producing CD4 T cells, as determined by the robust 2D micropipette adhesion assay that visualizes direct TCR:peptide-MHC ligand binding in a cell-based context (Figure 2A [81]). Notably, several genes associated with high TCR signal strength (e.g., Icos and Irf4) have been found to be upregulated in IL-21-producing CD4 T cells as compared to non-IL-21 producers [81,91]. Whether or not altering the binding affinity of the peptide-MHC class II to its TCR such that the peptide-MHC II: TCR binds more tightly actually leads to increased production of IL-21 and/or a conversion into an IL-21-producing CD4 T cell has not been formally tested.

IL21R is a common $\gamma$ chain receptor (IL2R, IL4R, IL7R, IL9R, and IL15R are others). Most lymphocyte populations (NK cells, B cells, and CD8 and CD4 T cells) express IL21R. TCR stimulation has been shown to induce IL21R upregulation [92]; whether cytokines or costimulatory molecules induce IL21R expression has not been determined. IL21R activation initiates a signaling cascade through the JAK/STAT pathway, predominantly mediated by STAT1 and STAT3 [93]. STAT5 may also contribute in IL21R signal transduction, as well as phosphatidylinositol 3-kinase (PI3K) and mitogen-activated protein kinase (MAPK) $[93,94]$. Some of the specific target genes downstream of IL21R activation include Gzma, Gzmb, Il10, Bim, Bcl6, Maf, Prdm1, Rorgt, Eomes, Socs1, and Socs3 [95]. Expression of genes for granzyme proteins fits with the effector-poised state of $T_{R M}$. In addition, Eomes is associated with promoting self-renewal of memory cells [96] and is upregulated by CD8 $\mathrm{T}$ cells during chronic infection [97]. A recent study has shown increased expression of Eomes by an inflammatory subset of CD8 $\mathrm{T}_{\mathrm{RM}}$ isolated from rectal mucosa of patients with ulcerative colitis [68].

IL21R signaling stimulates $B, T$, and NK cell proliferation and differentiation. In B cells, IL21R signaling can mediate proliferation and survival when combined with CD40:CD40L and BCR stimulation in the germinal center; when these other signals are absent, apoptosis may ensue [82,98,99]. In CD8 T cells and NK cells, IL21R signaling can also be proapoptotic or antiapoptotic depending on which other signaling pathways are concomitantly activated in the cell [16]. CD8 T cells stimulated with CD3 and simultaneously given IL-21 proliferate and increase IFN $\gamma$ production; CD8 T cells that received IL-21 treatment alone fail to express these functions [82]. When other cytokines such as IL-2 and IL-15 were added to CD8 T cells, addition of IL-21 enhanced CD8 T cell proliferation [82]. IL-21 stimulation has also been shown to influence $\mathrm{CD} 4$ regulatory $\mathrm{T}$ cell $\left(\mathrm{T}_{\mathrm{REG}}\right)$ differentiation; specifically that IL-21 treatment in vitro enhanced proliferation of human CD4 CD25- $\mathrm{T}$ cells and counteracted the suppressive activities of $\mathrm{CD} 4 \mathrm{CD} 25^{+} \mathrm{T}$ cells without affecting their survival [100]. Altogether, these data suggest that IL-21 tailors the immune response depending on which other stimulatory and cytokine receptors are co-engaged. 


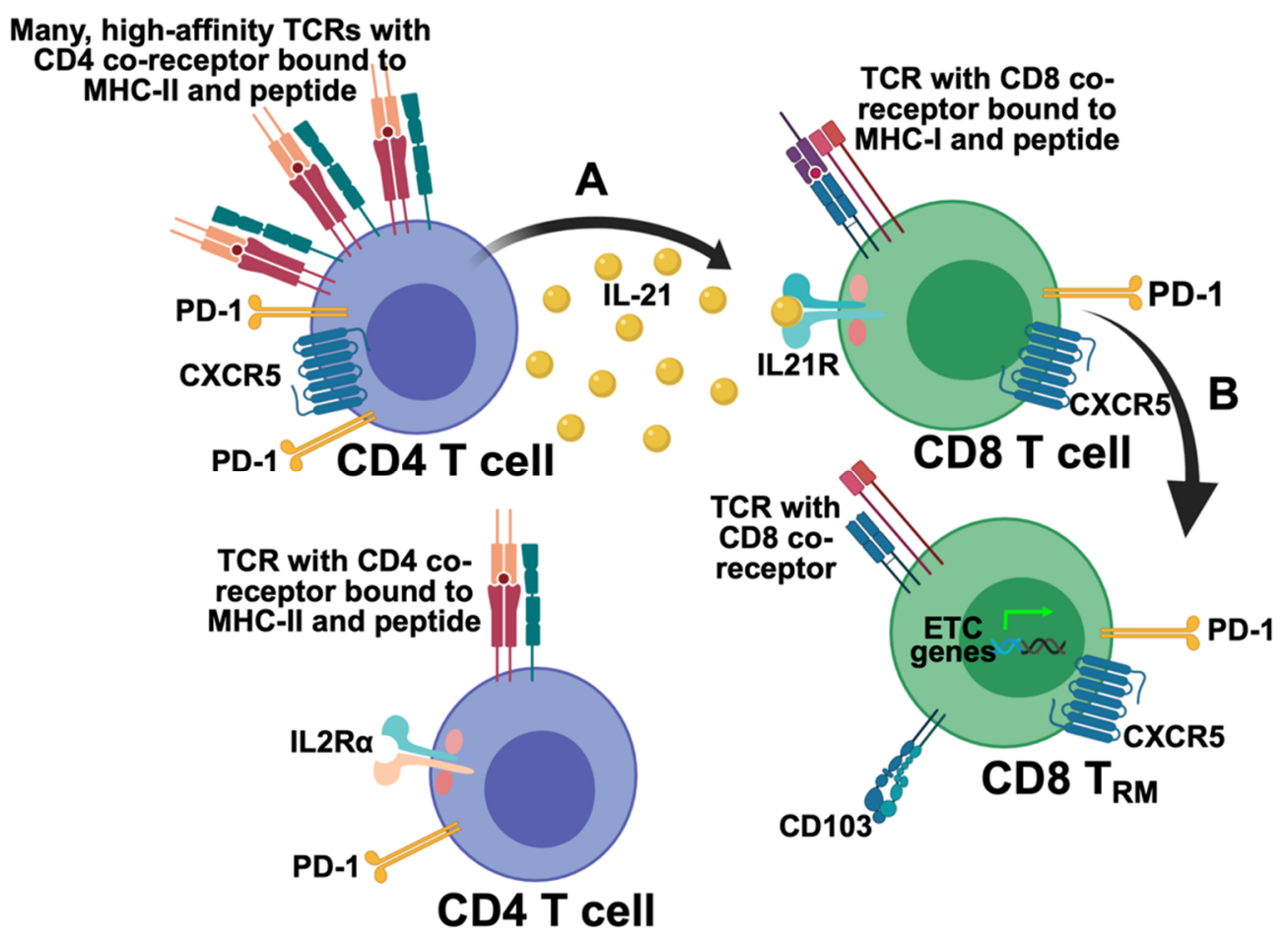

Figure 2. Proposed model of CD4 T cell-derived IL-21 help to CD8 T cells in the brain during PyV-infection. (A) CD4 T cells with a high density of high-affinity TCRs are CXCR5 ${ }^{\text {hi PD- }}$ ( $^{\text {hi }}$ and produce IL-21 that is received by the CD8 T cells in the brain. This is likely occurring around $15 \mathrm{dpi}$. (B) IL-21 binds to the IL21R on CD8 T cells and starts a signaling cascade that helps guide their differentiation into $\mathrm{bT}_{\mathrm{RM}}$, metabolically, phenotypically, and functionally. ETC, electron transport chain. Figure image created with BioRender.com.

\section{CD4 T Cell-Derived IL-21 Modulates the CD8 T cell Response}

CD4 T cell-derived IL-21 prevents CD8 T cell exhaustion during LCMV chronic infection [10-12], promotes CD8 T cell effector function during JHMV and T. gondii brain infections $[15,79,80]$, and directs $\mathrm{CD} 8 \mathrm{bT}_{\mathrm{RM}}$ differentiation and metabolism during MuPyV infection [81]. IL21R signaling as a potential regulator/promoter for oxidative metabolic pathways is also supported by work showing that IL-21 in vitro yielded CD8 T cells having an oxidative metabolic profile; specifically, IL-21 contributed to a reliance on fatty acid oxidation for fuel and a decrease in glycolysis [101]. This study further showed that IL-21 treatment decreased PD-1 expression and skewed toward a $\mathrm{T}_{\mathrm{CM}}$ phenotype [101]. Interestingly, although IL-21 treatment shifted CD8 T cells to oxidative phosphorylation/FAO, IL-21-treated CD8 $\mathrm{T}$ cells incorporated less BODIPY dye (a measure of intracellular fatty acid levels), suggesting that these cells were more reliant on intrinsically derived fatty acids which in some contexts has been more closely associated with $\mathrm{T}_{\mathrm{CM}}$ than $\mathrm{T}_{\mathrm{RM}}[81,101]$.

During chronic LCMV infection, IL-21 from CD4 T cells has been shown to direct CD8 T cells to develop into a $\mathrm{CX}_{3} \mathrm{CR} 1$-expressing subset that is more cytotoxic, more capable of viral control, and more responsive to immunomodulatory blockade than their $\mathrm{CX}_{3} \mathrm{CR} 1^{-}$counterparts [13]. In T. gondii-infected brains, PD-1 and IL21R expression were unrelated; however, IL21R ${ }^{-/-}$CD8 T cells had increased expression of other inhibitory molecules (i.e., 2B4, Lag3, and Tim-3) compared to their IL21R $^{+}$CD8 T cells [15], further supporting the idea that IL21R signaling in CD8 T cells offsets terminal exhaustion. The $\mathrm{CX}_{3} \mathrm{CR} 1^{+} \mathrm{CD} 8 \mathrm{~T}$ cells were found to express transcription factors and receptors more closely aligned with $\mathrm{T}_{\mathrm{RM}}$ or $\mathrm{T}_{\mathrm{CM}}$ than with $\mathrm{T}_{\mathrm{EX}}[13,102]$, raising the possibility that their metabolic profile may be more akin to that of $\mathrm{T}_{\mathrm{RM}}$ or $\mathrm{T}_{\mathrm{CM}}$. However, as shown in Figure 1 and discussed above, depending on tissue and pathogen context, these CD8 T cells may not neatly fall into a particular subset, but may instead possess mixed $\mathrm{T}_{\mathrm{RM}} / \mathrm{T}_{\mathrm{Ex}}$ or $\mathrm{T}_{\mathrm{CM}} / \mathrm{T}_{\mathrm{EX}}$ properties. 
Further evidence that IL-21/IL21R signaling drives CD8 T cells toward a metabolic profile more consistent with $\mathrm{T}_{\mathrm{RM}}$ comes from our recent work using MuPyV brain infection to define requirements for $\mathrm{bT}_{\mathrm{RM}}$ differentiation [81]. As depicted in Figure 2B, IL21R signaling in CD8 $\mathrm{T}$ cells in the brains of MuPyV-infected mice drives expression of genes within the electron transport chain (ETC) [81]. Expression of these genes connotes engagement of oxidative metabolism. In line with these findings, CD8 T cells in lungs of influenza virus-infected CD4 T cell-deficient mice express fewer oxidative metabolism genes and genes in complex I of the ETC [48]. Yet to be determined is whether the CD4 $\mathrm{T}$ cell help for lung CD8 $\mathrm{T}_{\mathrm{RM}}$ during influenza virus infection is provided by IL-21.

IL21R signaling in CD8 $\mathrm{T}$ cells during $\mathrm{T}_{\mathrm{RM}}$ differentiation occurs with concomitant high peptide-MHC-I: TCR engagement [82]. Thus, downstream factors from both IL21R and TCR signaling cascades likely interact to determine the functional and memory potential of the cell. A number of studies point toward specific transcription factors that may integrate IL21R and TCR signaling and thereby dictate development of $\mathrm{T}_{\mathrm{RM}}$. ChIP-seq genome-wide analyses have revealed that IL21R-induced STAT3 constitutively binds IRF4, a transcription factor known to increase proportional to the strength of TCR signaling [103]. Additionally, IL21R signaling induced binding of STAT3 and IRF4 to the $\operatorname{Prdm} 1$ gene (encoding Blimp1) [103]. Blimp1, along with Hobit, mediates $\mathrm{T}_{\mathrm{RM}}$ development in a number of tissues (Figure 1 [25]). IL21R signaling also induces BATF in CD8 T cells that may interact with TCR-induced IRF4 to maintain effector functions during chronic viral infection [14]. In addition, IL-21 also activates the PI3K-AKT-mammalian target of rapamycin (mTOR) pathway which plays an important role in T cell metabolism and differentiation [104,105]. Interestingly, mTOR contributes at least in part to regulating the expression of IRF4 in CD8 T cells, an interaction that may connect IL-21R signaling and metabolism to TCR signal strength $[106,107]$. Further work is needed to clarify how these transcription factors interact to guide $\mathrm{T}_{\mathrm{RM}}$ differentiation.

\section{Significance of CXCR5}

CXCR5 is a chemokine receptor known for migration of B cells from the dark zone into the light zone of germinal centers via gradients of its sole ligand CXCL13, which is produced by follicular dendritic cells. CXCR5-expressing $\mathrm{T}_{\mathrm{FH}}$ cells are also directed into germinal center light zones along a CXCL13 gradient. Thus, the CXCR5:CXCL13 axis colocalizes B cells with CD4 $\mathrm{T}_{\mathrm{FH}}$. We found that IL-21 producing CD4 T cells in the brain of MuPyV-infected mice highly express CXCR5 (Figure 2 [81]). Brain MuPyV-specific CD8 T cells also express CXCR5 [38]. Work by the Fabry group indicated that CXCL13 was expressed by inflamed endothelial cells in the brain following an infarct and served to recruit CXCR5 ${ }^{+}$IL21-producing CD4 T cells to sites of inflammation [108]. Although other mechanisms may be engaged to recruit $\mathrm{T}$ cells to the brain (e.g., CXCL9/10: CXCR3) [7,76,78], CXCL13:CXCR5 may act to aggregate CD4 and CD8 $\mathrm{T}$ cells in close proximity in nonlymphoid tissues and thereby facilitate CD4 T cell crosstalk with CD8 T cells. In this connection, CXCL13 ${ }^{+}$cells are present in the infected cerebral ventricular lining juxtaposed with aggregates of CD4 and CD8 T cells in the periventricular zone in brains of MuPyV-infected mice (HMR, unpublished observations). In studies on CD8 $\mathrm{T}_{\mathrm{EX}}$ cells during LCMV infection, CXCR5 expression has been associated with preferential expansion after PD-1 blockade $[63,109]$ and may also signify a more functional state. The association of CXCR5 with both PD-1 expression and IL-21 signaling also raises the question whether CXCR5 expression may equate with responsiveness to PD-1 blockade via CD4 T cell-derived IL-21.

\section{Concluding Remarks}

In certain persistently infected nonlymphoid organs, $\mathrm{T}_{\mathrm{EX}}$ and $\mathrm{T}_{\mathrm{RM}}$ have overlapping characteristics, such as expression of common transcription factors (Eomes, Blimp1), inhibitory receptors (PD1), and chemokine receptors (CXCR5). This blurred distinction between $\mathrm{T}_{\mathrm{EX}}$ and $\mathrm{T}_{\mathrm{RM}}$ is particularly evident in the brain, where CD8 $\mathrm{T}$ cell effector activities of both subsets must be tightly tuned to control persistent infection while concomitantly limiting bystander tissue damage in an organ replete with postmitotic cells. $\mathrm{T}_{\mathrm{EX}}$ and $\mathrm{T}_{\mathrm{RM}}$ both exist as heterogeneous populations, with recent evidence 
indicating that a proliferative progenitor-to-nonproliferative terminal cell pipeline maintains each of these subsets. CD4 T cell-derived IL-21 is emerging as an important regulator of CD8 $\mathrm{T}_{\mathrm{RM}}$ and $\mathrm{T}_{\mathrm{EX}}$ development, homeostasis, and function. Accumulating literature suggests that IL-21 mitigates progression to end-stage, nonfunctional $\mathrm{T}_{\mathrm{EX}}$ and promotes development of $\mathrm{T}_{\mathrm{RM}}$ in persistently infected tissues. Recent work further supports the likelihood that IL-21 is a critical factor in sustaining this essential heterogeneity in $\mathrm{T}_{\mathrm{EX}}$ and $\mathrm{T}_{\mathrm{RM}}$ populations. In nonlymphoid organs where off-target tissue damage can have devastating effects (e.g., brain), IL-21 may help guide CD8 T cells toward a mixed $\mathrm{T}_{\mathrm{RM}}-\mathrm{T}_{\mathrm{EX}}$ differentiation state and improve immunotherapy outcomes for chronic infections and cancer.

Author Contributions: Writing—original draft preparation, H.M.R.; writing-review and editing, H.M.R., A.E.L.; visualization, H.M.R. All authors have read and agreed to the published version of the manuscript.

Funding: National Institute of Neurological Disorders and Stroke and the National Institute of Allergy and Infectious Diseases of the National Institute of Health grant numbers R01NS088367 and R01NS092662 to A.E.L., and F31AI142997 to H.M.R. The content is solely the responsibility of the authors and does not necessarily represent the official views of the National Institutes of Health. This work was also supported by the Penn State College of Medicine Finkelstein Memorial Student Research Award to H.M.R.

Acknowledgments: Thank you to Colleen Netherby-Winslow, Matthew Lauver, Katie Ayers, and Sarah Carey for thoughtful comments and review of the manuscript.

Conflicts of Interest: The authors declare no conflict of interest.

\section{Abbreviations}

$\begin{array}{ll}\text { CIB } & \text { Checkpoint inhibitor blockade } \\ \text { FAO } & \text { Fatty acid oxidation } \\ \text { FRT } & \text { Female reproductive tract } \\ \text { i.c. } & \text { Intracranial } \\ \mathrm{IL} & \text { Interleukin } \\ \text { i.p. } & \text { Intraperitoneal } \\ \text { MuPyV } & \text { Mouse polyomavirus } \\ \text { PD-1 } & \text { Programed cell death receptor } 1 \\ \mathrm{~T}_{\mathrm{CM}} & \text { Central memory T cell } \\ \mathrm{T}_{\mathrm{EFF}} & \text { Effector T cell } \\ \mathrm{T}_{\mathrm{EM}} & \text { Effector memory T cell } \\ \mathrm{T}_{\mathrm{EX}} & \text { Exhausted T cell } \\ \mathrm{T}_{\mathrm{FH}} & \text { Follicular helper T cell } \\ \mathrm{T}_{\mathrm{REG}} & \text { Regulatory T cell } \\ \mathrm{T}_{\mathrm{RM}} & \text { Tissue resident memory T cell }\end{array}$

\section{References}

1. Martin, M.D.; Badovinac, V.P. Defining memory CD8 T cell. Front. Immunol. 2018, 9. [CrossRef] [PubMed]

2. Wherry, E.J.; Ahmed, R. Memory CD8 T-cell differentiation during viral infection. J. Virol. 2004, 78, 5535-5545. [CrossRef] [PubMed]

3. Rosato, P.C.; Wijeyesinghe, S.; Stolley, J.M.; Masopust, D. Integrating resident memory into T cell differentiation models. Curr. Opin. Immunol. 2020, 63, 35-42. [CrossRef] [PubMed]

4. Arens, R.; Schoenberger, S.P. Plasticity in programming of effector and memory CD8 ${ }^{+}$T-cell formation. Immunol. Rev. 2010, 235, 190-205. [CrossRef]

5. Matloubian, M.; Concepcion, R.J.; Ahmed, R. CD4 ${ }^{+} \mathrm{T}$ cells are required to sustain $\mathrm{CD} 8^{+}$cytotoxic T-cell responses during chronic viral infection. J. Virol. 1994, 68, 8056-8063. [CrossRef]

6. Battegay, M.; Moskophidis, D.; Rahemtulla, A.; Hengartner, H.; Mak, T.W.; Zinkernagel, R.M. Enhanced establishment of a virus carrier state in adult CD4 ${ }^{+}$T-cell-deficient mice. J. Virol. 1994, 68, 4700-4704. [CrossRef]

7. Mockus, T.E.; Shwetank; Lauver, M.D.; Ren, H.M.; Netherby, C.S.; Salameh, T.; Kawasawa, Y.I.; Yue, F.; Broach, J.R.; Lukacher, A.E. CD4 T cells control development and maintenance of brain-resident CD8 T cells during polyomavirus infection. PLoS Pathog. 2018, 14, e1007365. [CrossRef] 
8. Khan, I.A.; Hwang, S.; Moretto, M. Toxoplasma gondii: CD8 T cells cry for CD4 help. Front. Cell. Infect. Microbiol. 2019, 9. [CrossRef]

9. Hwang, S.; Cobb, D.A.; Bhadra, R.; Youngblood, B.; Khan, I.A. Blimp-1-mediated CD4 T cell exhaustion causes CD8 T cell dysfunction during chronic toxoplasmosis. J. Exp. Med. 2016, 213, 1799-1818. [CrossRef]

10. Fröhlich, A.; Kisielow, J.; Schmitz, I.; Freigang, S.; Shamshiev, A.T.; Weber, J.; Marsland, B.J.; Oxenius, A.; Kopf, M. IL-21R on T cells is critical for sustained functionality and control of chronic viral infection. Science 2009, 324, 1576-1580. [CrossRef]

11. Yi, J.S.; Du, M.; Zajac, A.J. A vital role for IL-21 in the control of a chronic viral infection. Science 2009, 324, 1572-1576. [CrossRef] [PubMed]

12. Elsaesser, H.; Sauer, K.; Brooks, D.G. IL-21 is required to control chronic viral infection. Science 2009, 324, 1569-1572. [CrossRef] [PubMed]

13. Zander, R.; Schauder, D.; Xin, G.; Nguyen, C.; Wu, X.; Zajac, A.; Cui, W. CD4 ${ }^{+}$T cell help is required for the formation of a cytolytic $\mathrm{CD} 8^{+} \mathrm{T}$ cell subset that protects against chronic infection and cancer. Immunity 2019, 51, 1028-1042. [CrossRef] [PubMed]

14. Xin, G.; Schauder, D.M.; Lainez, B.; Weinstein, J.S.; Dai, Z.; Chen, Y.; Esplugues, E.; Wen, R.; Wang, D.; Parish, I.A.; et al. A critical role of IL-21 Induced BATF in sustaining CD8 T cell mediated chronic viral control. Cell Rep. 2015, 13, 1118-1124. [CrossRef] [PubMed]

15. Moretto, M.M.; Hwang, S.; Khan, I.A. Downregulated IL-21 response and T Follicular helper cell exhaustion correlate with compromised CD8 T cell immunity during chronic Toxoplasmosis. Front. Immunol. 2017, 8. [CrossRef]

16. Tian, Y.; Zajac, A.J. IL-21 and T cell differentiaton: Consider the context. Trends Immunol. 2017, 37, 557-568. [CrossRef]

17. Schenkel, J.M.; Masopust, D. Tissue-resident memory T cells. Immunity 2014, 41, 886-897. [CrossRef]

18. Masopust, D.; Soerens, A.G. Tissue-resident T cells and other resident leukocytes. Annu. Rev. Immunol. 2019, 37, 521-546. [CrossRef]

19. Beltra, J.C.; Manne, S.; Abdel-Hakeem, M.S.; Kurachi, M.; Giles, J.R.; Chen, Z.; Casella, V.; Ngiow, S.F.; Khan, O.; Huang, Y.J.; et al. Developmental relationships of four exhausted CD8+ T cell subsets reveals underlying transcriptional and epigenetic landscape control mechanisms. Immunity 2020, 52, 825-841. [CrossRef]

20. Utzschneider, D.T.; Gabriel, S.S.; Chisanga, D.; Gloury, R.; Gubser, P.M.; Vasanthakumar, A.; Shi, W.; Kallies, A. Early precursor $\mathrm{T}$ cells establish and propagate $\mathrm{T}$ cell exhaustion in chronic infection. Nat. Immunol. 2020. [CrossRef]

21. Fonseca, R.; Beura, L.K.; Quarnstrom, C.F.; Ghoneim, H.E.; Fan, Y.; Zebley, C.C.; Scott, M.C.; Fares-Frederickson, N.J.; Wijeyesinghe, S.; Thompson, E.A.; et al. Developmental plasticity allows outside-in immune responses by resident memory T cells. Nat. Immunol. 2020, 21, 412-421. [CrossRef] [PubMed]

22. Stolley, J.M.; Johnston, T.S.; Soerens, A.G.; Beura, L.K.; Rosato, P.C.; Joag, V.; Wijeyesinghe, S.P.; Langlois, R.A.; Osum, K.C.; Mitchell, J.S.; et al. Retrograde migration supplies resident memory T cells to lung-draining $\ln$ after influenza infection. J. Exp. Med. 2020, 217, e20192197. [CrossRef] [PubMed]

23. Behr, F.M.; Parga-Vidal, L.; Kragten, N.A.M.; van Dam, T.J.P.; Wesselink, T.H.; Sheridan, B.S.; Arens, R.; van Lier, R.A.W.; Stark, R.; van Gisbergen, K.P.J.M. Tissue-resident memory CD8+ T cells shape local and systemic secondary T cell responses. Nat. Immunol. 2020, 21, 1070-1081. [CrossRef] [PubMed]

24. Stolarczyk, E.; Lord, G.M.; Howard, J.K. The immune cell transcription factor T-bet. Adipocyte 2014, 3, 58-62. [CrossRef]

25. Mackay, L.K.; Minnich, M.; Kragten, N.A.M.; Liao, Y.; Nota, B.; Seillet, C.; Zaid, A.; Man, K.; Preston, S.; Freestone, D.; et al. Hobit and Blimp1 instruct a universal transcriptional program of tissue residency in lymphocytes. Science 2016, 352, 459-463. [CrossRef]

26. Wherry, E.J.; Ha, S.J.; Kaech, S.M.; Haining, W.N.; Sarkar, S.; Kalia, V.; Subramaniam, S.; Blattman, J.N.; Barber, D.L.; Ahmed, R. Molecular signature of $\mathrm{CD}^{+} \mathrm{T}$ cell exhaustion during chronic viral infection. Immunity 2007, 27, 670-684. [CrossRef]

27. Martinez, G.; Pereira, R.M.; Äijö, T.; Kim, E.Y.; Marangoni, F.; Pipkin, M.E.; Togher, S.; Heissmeyer, V.; Zhang, Y.C.; Crotty, S.; et al. The transcription factor NFAT promotes exhaustion of activated CD8 ${ }^{+}$T cells. Immunity 2016, 42, 265-278. [CrossRef] 
28. Man, K.; Gabriel, S.S.; Liao, Y.; Gloury, R.; Preston, S.; Henstridge, D.C.; Pellegrini, M.; Zehn, D.; Berberich-Siebelt, F.; Febbraio, M.A.; et al. Transcription factor IRF4 promotes CD8 ${ }^{+} \mathrm{T}$ cell exhaustion and limits the development of memory-like T cells during chronic infection. Immunity 2017, 47, 1129-1141.e5. [CrossRef]

29. Khan, O.; Giles, J.R.; McDonald, S.; Manne, S.; Ngiow, S.F.; Patel, K.P.; Werner, M.T.; Huang, A.C.; Alexander, K.A.; Wu, J.E.; et al. TOX transcriptionally and epigenetically programs $\mathrm{CD}^{+} \mathrm{T}$ cell exhaustion. Nature 2019, 571, 211-218. [CrossRef]

30. Alfei, F.; Kanev, K.; Hofmann, M.; Wu, M.; Ghoneim, H.E.; Roelli, P.; Utzschneider, D.T.; von Hoesslin, M.; Cullen, J.G.; Fan, Y.; et al. TOX reinforces the phenotype and longevity of exhausted T cells in chronic viral infection. Nature 2019, 571, 265-269. [CrossRef]

31. Scott, A.C.; Dündar, F.; Zumbo, P.; Chandran, S.S.; Klebanoff, C.A.; Shakiba, M.; Trivedi, P.; Menocal, L.; Appleby, H.; Camara, S.; et al. TOX is a critical regulator of tumour-specific T cell differentiation. Nature 2019, 571, 270-274. [CrossRef] [PubMed]

32. Yao, C.; Sun, H.W.; Lacey, N.E.; Ji, Y.; Moseman, E.A.; Shih, H.Y.; Heuston, E.F.; Kirby, M.; Anderson, S.; Cheng, J.; et al. Single-cell RNA-seq reveals TOX as a key regulator of CD8 ${ }^{+} \mathrm{T}$ cell persistence in chronic infection. Nat. Immunol. 2019, 20, 890-901. [CrossRef] [PubMed]

33. Seo, H.; Chen, J.; Samaniego-Castruita, D.; Wang, Y.H.; López-moyado, I.F.; Georges, R.O.; Zhang, W.; Onodera, A.; Wu, C.-J.; Lu, L.-F.; et al. TOX and TOX2 transcription factors cooperate with NR4A transcription factors to impose CD8 ${ }^{+}$Tcell exhaustion. Proc. Natl. Acad. Sci. USA 2019, 116, 19761. [CrossRef] [PubMed]

34. Rutishauser, R.L.; Martins, G.A.; Kalachikov, S.; Chandele, A.; Parish, I.A.; Meffre, E.; Jacob, J.; Calame, K.; Kaech, S.M. Blimp-1 promotes terminal differentiation of virus-specific CD8 T cells and represses the acquisition of central memory T cell properties. Immunity 2009, 31, 296-308. [CrossRef] [PubMed]

35. Walsh, D.A.; Borges, H.; Beura, L.K.; Peng, C.; Hamilton, S.E.; Masopust, D.; Jameson, S.C. The functional requirement for $\mathrm{CD} 69$ in establishment of resident memory $\mathrm{CD} 8{ }^{+} \mathrm{T}$ cells varies with tissue location. J. Immunol. 2019, 203, 946-955. [CrossRef]

36. Mackay, L.K.; Rahimpour, A.; Ma, J.Z.; Collins, N.; Stock, A.T.; Hafon, M.-L.; Vega-Ramos, J.; Lauzurica, P.; Mueller, S.N.; Stefanovic, T.; et al. The developmental pathway for CD103 ${ }^{+} \mathrm{CD}{ }^{+}$tissue-resident memory T cells of skin. Nat. Immunol. 2013, 14, 1294-1301. [CrossRef]

37. Wakim, L.M.; Woodward-Davis, A.; Liu, R.; Hu, Y.; Smyth, G.; Bevan, M.J.; Villadangos, J.; Smyth, G.; Bevan, M.J. The molecular signature of tissue resident memory CD8 T cells isolated from the brain. J. Immunol. 2014, 189, 3462-3471. [CrossRef]

38. Shwetank; Abdelsamed, H.A.; Frost, E.L.; Schmitz, H.M.; Mockus, T.E.; Youngblood, B.A.; Lukacher, A.E. Maintenance of PD-1 on brain-resident memory CD8 T cells is antigen independent. Immunol. Cell Biol. 2017, 95, 953-959. [CrossRef]

39. Mockus, T.E.; Ren, H.M.; Lukacher, A.E. To go or stay: The development, benefit, and detriment of tissue-resident memory CD8 T cells during central nervous system viral infections. Viruses 2019, 11, 842. [CrossRef]

40. Wakim, L.M.; Woodward-Davis, A.; Bevan, M.J. Memory T cells persisting within the brain after local infection show functional adaptations to their tissue of residence. Proc. Natl. Acad. Sci. USA 2010, 107, 17872-17879. [CrossRef]

41. Steinbach, K.; Vincenti, I.; Kreutzfeldt, M.; Page, N.; Muschaweckh, A.; Wagner, I.; Drexler, I.; Pinschewer, D.; Korn, T.; Merkler, D. Brain-resident memory T cells represent an autonomous cytotoxic barrier to viral infection. J. Exp. Med. 2016, 213, 1571-1587. [CrossRef]

42. Landrith, T.A.; Sureshchandra, S.; Rivera, A.; Jang, J.C.; Rais, M.; Nair, M.G.; Messaoudi, I.; Wilson, E.H. $\mathrm{CD}_{103}{ }^{+} \mathrm{CD} 8 \mathrm{~T}$ cells in the Toxoplasma-infected brain exhibit a tissue-resident memory transcriptional profile. Front. Immunol. 2017, 8, 335. [CrossRef] [PubMed]

43. Frost, E.L.; Mockus, T.E.; Ren, H.M.; Toprak, M.; Lauver, M.D.; Netherby-Winslow, C.S.; Jin, G.; Cosby, J.M.; Evavold, B.D.; Lukacher, A.E. PD-1 dynamically regulates inflammation and development of brain-resident memory CD8 T cells during persistent viral encephalitis. Front. Immunol. 2019, 10. [CrossRef]

44. Frost, E.L.; Kersh, A.E.; Evavold, B.D.; Lukacher, A.E. Cutting edge: Resident memory CD8 T cells express high-affinity TCRs. J. Immunol. 2015, 195, 1501521. [CrossRef] [PubMed]

45. Yi, J.S.; Cox, M.A.; Zajac, A.J. T-cell exhaustion: Characteristics, causes and conversion. Immunology 2010, 129, 474-481. [CrossRef] [PubMed] 
46. Sullivan, D.O.; Van Der Windt, G.J.W.; Huang, S.C.; Curtis, J.D.; Chang, C.; Buck, M.D.; Qiu, J.; Smith, A.M.; Lam, W.Y.; Diplato, L.M.; et al. Memory CD8 ${ }^{+}$T cells use cell-intrinsic lipolysis to support the metabolic programming necessary for development. Immunity 2014, 41, 75-88. [CrossRef] [PubMed]

47. Pan, Y.; Tian, T.; Park, C.O.; Lofftus, S.Y.; Mei, S.; Liu, X.; Puigserver, P.; Krueger, J.G.; Hotamisligil, G.S.; Rachael, A. Survival of tissue-resident memory $\mathrm{T}$ cells requires exogenous lipid uptake and metabolism. Nature 2017, 543, 252-256. [CrossRef]

48. Cullen, J.G.; Mcquilten, H.A.; Quinn, K.M.; Olshansky, M.; Russ, B.E.; Morey, A.; Wei, S.; Prier, J.E.; La, N.L.; Doherty, P.C.; et al. CD4 ${ }^{+}$T help promotes influenza virus-specific $\mathrm{CD}^{+} \mathrm{T}$ cell memory by limiting metabolic dysfunction. Proc. Natl. Acad. Sci. USA 2019, 116, 4481-4488. [CrossRef]

49. Saeidi, A.; Zandi, K.; Cheok, Y.Y.; Saeidi, H.; Wong, W.F.; Lee, C.Y.Q.; Cheong, H.C.; Yong, Y.K.; Larsson, M.; Shankar, E.M. T-cell exhaustion in chronic infections: Reversing the state of exhaustion and reinvigorating optimal protective immune responses. Front. Immunol. 2018, 9. [CrossRef]

50. Masopust, D.; Vezys, V.; Marzo, A.L.; Lefrançois, L. Preferential localization of effector memory cells in nonlymphoid tissue. Science 2001, 291, 2413-2417. [CrossRef]

51. Schenkel, J.M.; Fraser, K.A.; Beura, L.K.; Pauken, K.E.; Vezys, V.; Masopust, D. Resident memory CD8 T cells trigger protective innate and adaptive immune responses. Science 2014, 346, 98-101. [CrossRef] [PubMed]

52. Ariotti, S.; Hogenbirk, M.; Dijkgraaf, F.; Visser, L.; Hoekstra, M.; Song, J.-Y.; Jacobs, H.; Haanen, J.; Schumacher, T. Skin-resident memory $\mathrm{CD}^{+} \mathrm{T}$ cells trigger a state of tissue-wide pathogen alert. Science 2014, 346, 101-105. [CrossRef] [PubMed]

53. Klonowski, K.D.; Williams, K.J.; Marzo, A.L.; Blair, D.A.; Lingenheld, E.G.; Lefrançois, L. Dynamics of blood-borne CD8 memory T cell migration in vivo. Immunity 2004, 20, 551-562. [CrossRef]

54. Tomura, M.; Yoshida, N.; Tanaka, J.; Karasawa, S.; Miwa, Y.; Miyawaki, A.; Kanagawa, O. Monitoring cellular movement in vivo with photoconvertible fluorescence protein "Kaede" transgenic mice. Proc. Natl. Acad. Sci. USA 2008, 105, 10871-10876. [CrossRef]

55. Anderson, K.G.; Mayer-Barber, K.; Sung, H.; Beura, L.; James, B.R.; Taylor, J.J.; Qunaj, L.; Griffith, T.S.; Vezys, V.; Barber, D.L.; et al. Intravascular staining for discrimination of vascular and tissue leukocytes. Nat. Protoc. 2014, 9, 209-222. [CrossRef] [PubMed]

56. Cole, G.A.; Nathanson, N.; Prendergast, R.A. Requirement for $\Theta$-bearing cells in lymphocytic choriomeningitis virus-induced central nervous system disease. Nature 1972, 238, 335-337. [CrossRef] [PubMed]

57. Lugli, E.; Galletti, G.; Boi, S.K.; Youngblood, B.A. Stem, effector, and hybrid states of memory CD8 ${ }^{+} \mathrm{T}$ cells. Trends Immunol. 2020, 41, 17-28. [CrossRef]

58. Youngblood, B.; Noto, A.; Porichis, F.; Akondy, R.S.; Ndhlovu, Z.M.; Austin, J.W.; Bordi, R.; Procopio, F.A.; Miura, T.; Allen, T.M.; et al. Cutting edge: Prolonged exposure to HIV reinforces a poised epigenetic program for PD-1 expression in virus-specific CD8 T cells. J. Immunol. 2013, 191, 540-544. [CrossRef]

59. Hashimoto, M.; Kamphorst, A.O.; Im, S.J.; Kissick, H.T.; Pillai, R.N.; Ramalingam, S.S.; Araki, K.; Ahmed, R. CD8 $\mathrm{T}$ cell exhaustion in chronic infection and cancer: Opportunities for interventions. Annu. Rev. Med. 2018, 69, 301-318. [CrossRef]

60. Gallimore, B.A.; Glithero, A.; Godkin, A.; Tissot, A.C.; Plückthun, A.; Elliott, T.; Hengartner, H.; Zinkernagel, R. Induction and exhaustion of lymphocytic choriomeningitis virus-specific cytotoxic T lymphocytes visualized using class I-peptide complexes. J. Exp. Med. 1998, 187, 1383-1393. [CrossRef]

61. Ahmed, R.; Salmi, A.; Butler, L.D.; Chiller, J.M.; Oldstone, M.B.A. Selection of genetic variants of lymphocytic choriomeningitis virus in spleens of persistently infected mice. J. Exp. Med. 1984, 60, 521-540. [CrossRef]

62. Wang, Y.; Hu, J.; Li, Y.; Xiao, M.; Wang, H.; Tian, Q.; Li, Z.; Tang, J.; Hu, L.; Tan, Y.; et al. The transcription factor Tcf1 preserves the effector function of exhausted CD8 T cells during chronic viral infection. Front. Immunol. 2019, 10. [CrossRef] [PubMed]

63. Im, S.J.; Hashimoto, M.; Gerner, M.Y.; Lee, J.J.; Kissick, H.T.; Burger, M.C.; Shan, Q.; Hale, J.S.; Lee, J.J.; Nasti, T.H.; et al. Defining CD8 ${ }^{+}$T cells that provide the proliferative burst after PD-1 therapy. Nature 2016, 537, 417-421. [CrossRef] [PubMed]

64. Mackay, L.K.; Wynne-Jones, E.; Freestone, D.; Pellicci, D.G.; Mielke, L.A.; Newman, D.M.; Braun, A.; Masson, F.; Kallies, A.; Belz, G.T.; et al. T-box transcription factors combine with the cytokines TGF- $\beta$ and IL-15 to control tissue-resident memory T cell fate. Immunity 2015, 43, 1101-1111. [CrossRef] [PubMed]

65. Ma, C.; Mishra, S.; Demel, E.L.; Liu, Y.; Zhang, N. TGF- $\beta$ controls the formation of kidney-resident T cells via promoting effector T cell extravasation. J. Immunol. 2017, 198, 749-756. [CrossRef] [PubMed] 
66. Sanecka, A.; Yoshida, N.; Kolawole, E.M.; Patel, H.; Evavold, B.D.; Frickel, E.M. T cell receptor-major histocompatibility complex interaction strength defines trafficking and CD103 ${ }^{+}$memory status of CD8 T cells in the brain. Front. Immunol. 2018, 9. [CrossRef] [PubMed]

67. Smolders, J.; Heutinck, K.M.; Fransen, N.L.; Remmerswaal, E.B.M.; Hombrink, P.; Berge, I.J.M.; Van Lier, R.A.W.; Huitinga, I.; Hamann, J. Tissue-resident memory T cells populate the human brain. Nat. Commun. 2018, 9. [CrossRef]

68. Boland, A.B.S.; He, Z.; Tsai, M.S.; Olvera, J.G.; Omilusik, K.D.; Duong, H.G.; Kim, E.S.; Limary, A.E.; Jin, W.; Milner, J.J.; et al. Heterogeneity and clonal relationships of adaptive immune cells in ulcerative colitis revealed by single-cell RNA and antigen-receptor sequencing analyses. Sci. Immunol. 2020, 5, eabb4432. [CrossRef]

69. Ahn, E.; Araki, K.; Hashimoto, M.; Li, W.; Riley, J.L.; Cheung, J.; Sharpe, A.H.; Freeman, G.J.; Irving, B.A.; Ahmed, R. Role of PD-1 during effector CD8 T cell differentiation. Proc. Natl. Acad. Sci. USA 2018, 115, 4749-4754. [CrossRef] [PubMed]

70. Prasad, S.; Hu, S.; Sheng, W.S.; Chauhan, P.; Singh, A.; Lokensgard, J.R. The PD-1: PD-L1 pathway promotes development of brain-resident memory T cells following acute viral encephalitis. J. Neuroinflamm. 2017, 14, 1-13. [CrossRef]

71. Bhadra, R.; Gigley, J.P.; Khan, I.A. PD-1-mediated attrition of polyfunctional memory CD8 ${ }^{+} \mathrm{T}$ cells in chronic toxoplasma infection. J. Infect. Dis. 2012, 206, 125-134. [CrossRef] [PubMed]

72. Phares, T.W.; Ramakrishna, C.; Parra, G.I.; Epstein, A.; Chen, L.; Atkinson, R.; Stohlman, S.A.; Bergmann, C.C. Target-dependent B7-H1 regulation contributes to clearance of central nervous sysyem infection and dampens morbidity. J. Immunol. 2009, 182, 5430-5438. [CrossRef] [PubMed]

73. Cortese, I.; Muranski, P.; Enose-Akahata, Y.; Ha, S.; Smith, B.; Monaco, M.; Ryschkewitsch, C.; Major, E.; Ohayon, J.; Schindler, M.; et al. Pembrolizumab treatment for progressive multifocal leukoencephalopathy. N. Engl. J. Med. 2019, 280, 1597-1605. [CrossRef] [PubMed]

74. Hoang, E.; Bartlett, N.; Goyal, M.S.; Schmidt, R.E.; Clifford, D.B. Progressive multifocal leukoencephalopathy treated with nivolumab. J. Neurovirol. 2019, 25, 284-287. [CrossRef] [PubMed]

75. Lin, R.; Zhang, H.; Yuan, Y.; He, Q.; Zhou, J.; Li, S.; Sun, Y.; Li, D.Y.; Qiu, H.; Wang, W.; et al. Fatty acid oxidation controls $\mathrm{CD}^{+}$tissue-resident memory $\mathrm{T}$ cell survival in gastric adenocarcinoma. Cancer Immunol. Res. 2020, 8. [CrossRef] [PubMed]

76. Laidlaw, B.J.; Zhang, N.; Marshall, H.D.; Staron, M.M.; Guan, T.; Hu, Y.; Cauley, L.S.; Craft, J.; Kaech, S.M. $\mathrm{CD}^{+} \mathrm{T}$ cell help guides formation of $\mathrm{CD} 103^{+}$lung-resident memory $\mathrm{CD} 8^{+} \mathrm{T}$ cells during influenza viral infection. Immunity 2014. [CrossRef]

77. Laidlaw, B.J.; Craft, J.E.; Kaech, S.M. The multifaceted role of CD4 ${ }^{+} \mathrm{T}$ cells in $\mathrm{CD} 8^{+} \mathrm{T}$ cell memory. Nat. Rev. Immunol. 2016, 16. [CrossRef]

78. Nakanishi, Y.; Lu, B.; Gerard, C.; Iwasaki, A. CD8 ${ }^{+}$T lymphocyte mobilization to virus-infected tissue requires $\mathrm{CD}^{+}{ }^{+}$T-cell help. Nature 2009. [CrossRef]

79. Phares, T.W.; Marques, C.P.; Stohlman, S.A.; Hinton, D.R.; Bergmann, C.C. Factors supporting intrathecal humoral responses following viral encephalomyelitis. J. Virol. 2011, 85, 2589-2598. [CrossRef]

80. Phares, T.W.; Disano, K.D.; Hinton, D.R.; Hwang, M.; Zajac, A.J.; Stohlman, S.A.; Bergmann, C.C. IL-21 optimizes $\mathrm{T}$ cell and humoral responses in the central nervous system during viral encephalitis. J. Neuroimmunol. 2013, 263, 43-54. [CrossRef]

81. Ren, H.M.; Kolawole, E.M.; Ren, M.; Jin, G.; Netherby-Winslow, C.S.; Wade, Q.; Shwetank; Rahman, Z.S.M.; Evavold, B.D.; Lukacher, A.E. IL-21 from high-affinity CD4 T cells drives differentiation of brain-resident CD8 T cells during persistent viral infection. Sci. Immunol. 2020. [CrossRef]

82. Parrish-Novak, J.; Dillon, S.R.; Nelson, A.; Hammond, A.; Sprecher, C.; Gross, J.A.; Johnston, J.; Madden, K.; $\mathrm{Xu}, \mathrm{W}$.; West, J.; et al. Interleukin 21 and its receptor are involved in NK cell expansion and regulation of lymphocyte function. Nature 2000, 408, 57-63. [CrossRef] [PubMed]

83. Crotty, S. Follicular Helper CD4 T cells $\left(\mathrm{T}_{\mathrm{FH}}\right)$. Annu. Rev. Immunol. 2011. [CrossRef] [PubMed]

84. Crotty, S. T Follicular helper cell differentiation, function, and roles in disease. Immunity 2014, 41, 529-542. [CrossRef]

85. Zhang, F.; Pang, N.; Zhu, Y.; Zhou, D.; Zhao, H.; Hu, J.; Ma, X.; Li, J. CCR7'lo PD-1 ${ }^{\text {hi }}$ CXCR5 ${ }^{+}$CD4 ${ }^{+}$ $\mathrm{T}$ cells are positively correlated with levels of IL-21 in active and transitional cystic echinococcosis patients. BMC Infect. Dis. 2015, 15. [CrossRef] 
86. Fan, X.; Jin, T.; Zhao, S.; Liu, C.; Han, J.; Jiang, X. Circulating CCR7 ${ }^{+}$ICOS $^{+}$memory T follicular helper cells in patients with multiple sclerosis. PLoS ONE 2015, 10, e0134523. [CrossRef]

87. Jain, S.; Stock, A.; Macian, F.; Putterman, C. A distinct T follicular helper cell subset infiltrates the brain in murine neuropsychiatric lupus. Front. Immunol. 2018, 9, 487. [CrossRef]

88. Strengell, M.; Julkunen, I.; Matikainen, S. IFN- $\alpha$ regulates IL-21 and IL-21R expression in human NK and T cells. J. Leukoc. Biol. 2004, 76, 416-422. [CrossRef]

89. Nurieva, R.; Yang, X.O.; Martinez, G.; Zhang, Y.; Panopoulos, A.D.; Ma, L.; Schluns, K.; Tian, Q.; Watowich, S.S.; Jetten, A.M.; et al. Essential autocrine regulation by IL-21 in the generation of inflammatory T cells. Nature 2007, 448, 480-484. [CrossRef]

90. Ditoro, D.; Winstead, C.J.; Pham, D.; Witte, S.; Andargachew, R.; Singer, J.R.; Wilson, C.G.; Zindl, C.L.; Luther, R.J.; Silberger, D.J.; et al. Differential IL-2 expression defines developmental fates of follicular versus nonfollicular helper T cells. Science. 2018, 361, eaao2933. [CrossRef]

91. Marnik, E.A.; Wang, X.; Sproule, T.J.; Park, G.; Gregory, J.; Lane-reticker, S.K.; Jain, S.; Duffy, T.; Carter, G.W.; Iii, H.C.M.; et al. Precocious interleukin 21 expression in naïve mice identifies a natural helper cell population in autoimmune disease. Cell Rep. 2017, 21, 208-221. [CrossRef] [PubMed]

92. Wu, Z.; Kim, H.; Xue, H.; Liu, H.; Zhao, K.; Leonard, W.J. Interleukin-21 receptor gene induction in human T cells is mediated by T-cell receptor-induced Sp1 activity. Mol. Cell. Biol. 2005, 25, 9741-9752. [CrossRef] [PubMed]

93. Zeng, R.; Spolski, R.; Casas, E.; Zhu, W.; Levy, D.E.; Leonard, W.J. The molecular basis of IL-21-mediated proliferation. Blood 2007, 109, 4135-4142. [CrossRef] [PubMed]

94. R\&D Systems. IL-21 Signaling Pathways. Available online: https://www.rndsystems.com/pathways/il21signaling-pathways (accessed on 21 September 2020).

95. Spolski, R.; Leonard, W.J. Interleukin-21: A double-edged sword with therapeutic potential. Nat. Rev. 2014, 13, 379-395. [CrossRef]

96. Banerjee, A.; Gordon, S.M.; Intlekofer, A.M.; Paley, M.A.; Mooney, E.C.; Lindsten, T.; Wherry, E.J.; Reiner, S.L. Cutting edge: The transcription factor eomesodermin enables $\mathrm{CD}^{+} \mathrm{T}$ cells to compete for the memory cell niche. J. Immunol. 2010, 185, 4988-4992. [CrossRef]

97. Paley, M.A.; Kroy, D.C.; Odorizzi, P.M.; Johnnidis, J.B.; Dolfi, D.V.; Barnett, B.E.; Bikoff, E.K.; Robertson, E.J.; Lauer, G.M.; Reiner, S.L.; et al. Progenitor and terminal subsets of $\mathrm{CD} 8^{+} \mathrm{T}$ cells cooperate to contain chronic viral infection. Science 2012, 338, 1220-1225. [CrossRef]

98. Ozaki, K.; Spolski, R.; Ettinger, R.; Kim, H.-P.; Wang, G.; Qi, C.-F.; Hwu, P.; Shaffer, D.J.; Akilesh, S.; Roopenian, D.C.; et al. Regulation of B cell differentiation and plasma cell Ggeneration by IL-21, a novel inducer of Blimp-1 and Bcl-6. J. Immunol. 2004, 173, 5361-5371. [CrossRef]

99. Yoshizaki, A.; Miyagaki, T.; Dilillo, D.J.; Matsushita, T.; Horikawa, M.; Kountikov, E.I.; Spolski, R.; Poe, J.C.; Leonard, W.J.; Tedder, T.F. Regulatory B cells control T-cell autoimmunity through IL-21-dependent cognate interactions. Nature 2012, 491, 264-268. [CrossRef]

100. Peluso, I.; Fantini, M.C.; Fina, D.; Caruso, R.; Boirivant, M.; MacDonald, T.T.; Pallone, F.; Monteleone, G. IL-21 counteracts the regulatory $\mathrm{T}$ cell-mediated suppression of human $\mathrm{CD} 4^{+} \mathrm{T}$ lymphocytes. J. Immunol. 2007, 178, 732-739. [CrossRef]

101. Loschinski, R.; Böttcher, M.; Stoll, A.; Bruns, H.; Mackensen, A.; Mougiakakos, D. IL-21 modulates memory and exhaustion phenotype of T-cells in a fatty acid oxidation-dependent manner. Oncotarget 2018, 9, 13125-13138. [CrossRef]

102. Hudson, W.H.; Gensheimer, J.; Hashimoto, M.; Wieland, A.; Valanparambil, R.M.; Li, P.; Lin, J.X.; Konieczny, B.T.; Im, S.J.; Freeman, G.J.; et al. Proliferating transitory T cells with an effector-like transcriptional signature emerge from PD-1 ${ }^{+}$stem-like CD8 ${ }^{+}$T cells during chronic infection. Immunity 2019, 51, 1043-1058. [CrossRef] [PubMed]

103. Kwon, H.; Thierry-mieg, D.; Thierry-mieg, J.; Kim, H.; Tunyaplin, C.; Carotta, S.; Donovan, C.E.; Matthew, L.; Tailor, P.; Ozato, K.; et al. Analysis of interleukin-21-induced Prdm1 gene regulation reveals functional cooperation of STAT3 and IRF4 transcription factors. Immunity 2012, 31, 941-952. [CrossRef] [PubMed]

104. Saleiro, D.; Platanias, L.C. Intersection of mTOR and STAT signaling in immunity. Trends Immunol. 2015, 36, 21-29. [CrossRef]

105. Araki, K.; Turner, A.P.; Shaffer, V.O.; Gangappa, S.; Keller, S.A.; Bachmann, M.F.; Larsen, C.P.; Ahmed, R. mTOR regulates memory CD8 T cell differentiation. Nature 2010, 460, 108-112. [CrossRef] [PubMed] 
106. Man, K.; Miasari, M.; Shi, W.; Xin, A.; Henstridge, D.C.; Preston, S.; Pellegrini, M.; Belz, G.T.; Smyth, G.K.; Febbraio, M.A.; et al. The transcription factor IRF4 is essential for TCR affinity-mediated metabolic programming and clonal expansion of T cells. Nat. Immunol. 2013, 14, 1155-1165. [CrossRef]

107. Yao, S.; Buzo, B.F.; Pham, D.; Jiang, L.; Taparowsky, E.J.; Kaplan, M.H.; Sun, J. Interferon regulatory factor 4 sustains $\mathrm{CD}^{+} \mathrm{T}$ cell expansion and effector differentiation. Immunity 2013, 39, 833-845. [CrossRef]

108. Kissel, L.T.; Rayasam, A.; Kijak, J.; Choi, Y.H.; Hsu, M.; Kovacs, K.; Sandor, M.; Fabry, Z. T follicular helper cell recruitment to the ischemic brain. J. Immunol. 2019, 202 (Suppl. S1), 121.10.

109. Wu, T.; Ji, Y.; Moseman, E.A.; Xu, H.C.; Manglani, M.; Kirby, M.; Anderson, S.M.; Handon, R.; Kenyon, E.; Elkahloun, A.; et al. The TCF1-Bcl6 axis counteracts type I interferon to repress exhaustion and maintain T cell stemness. Sci. Immunol. 2016, 1. [CrossRef]

C 2020 by the authors. Licensee MDPI, Basel, Switzerland. This article is an open access article distributed under the terms and conditions of the Creative Commons Attribution (CC BY) license (http://creativecommons.org/licenses/by/4.0/). 